\title{
Comparative Leaf Anatomy of Selected Medicinal Plants in Acanthaceae
}

\author{
Che Nurul Aini Che Amri ${ }^{1}$, Nur Shuhada Tajudin ${ }^{1}$, Rozilawati Shahari ${ }^{1}$, Fatin Munirah Azmi ${ }^{1}$, Noraini Talip ${ }^{2}$, \\ Abdul Latiff Mohamad ${ }^{2}$ \\ ${ }^{1}$ Dept. of Plant Science, Kulliyyah of Science, International Islamic University Malaysia Kuantan. \\ ${ }^{2}$ School of Environmental and Natural Resource Sciences, Faculty of Science and Technology, Universiti \\ Kebangsaan Malaysia.
}

\begin{abstract}
Comparative leaf anatomy study were conducted in three taxa of Acanthaceae from peninsular Malaysia. Three chosen taxa were Acanthus ebracreatus (Vahl), Andrographis paniculata (Burm.f.) Wall. ex Nees and Chroesthes longifolia (Wight) B. Hansen which is commonly used as traditional medicine especially in peninsular Malaysia. The main objective is to identify the leaf anatomical characteristics that can be used in plant identification and also for supportive data in plant classification. The procedures involved such as cross section using sliding microtome on the petiole, lamina, midribs and marginal, leaf clearing and observation under light microscope. Results have shown the similarities and variations in leaf anatomical characteristics. The anatomical characteristics observed include petiole and midrib outlines, patterns of petiole and midrib vascular bundles, presence of cystolith cells, presence of hypodermis layers in lamina and presence and types of trichomes. In conclusion, results showed that anatomical characteristics have taxonomic significance that can be used in classification especially at species level.
\end{abstract}

\section{INTRODUCTION}

Previous research by one of the earliest Muslim known as Al-Dinawari contributed knowledge in botany especially flora in Arabia. His research is considered to be as one the most comprehensive and methodical philologically-oriented work in botany. Nowadays, Muslims are making new discoveries in plant botany especially medicinal plants. The use of medicinal plants in Islamic culture was in vogue for a long time, with a few plants being mentioned in the Holy Quran and Hadith (PBUH). ${ }^{1}$ Saad reports that the characterisation of the biological and pharmacological effects of herbal-based medicine has been in demand recently. ${ }^{2}$ It is becoming more complex with the collaboration from other research areas such as botany, chemistry, biotechnology and bioinformatics. One of the major uses of plants and herbs are for healing purposes which include diabetes, obesity and infertility. ${ }^{2}$ Recently, herbal medicines has been recognized as one of the complementary or alternative medicines especially in Malaysia.

The Acanthaceae family is recognised as a large pantropical family of herbs and shrubs. ${ }^{3}$ Acanthaceae family belongs to the order Lamiales which has at

Corresponding author:

Che Nurul Aini Che Amri

Department of Plant Science,

Kulliyyah of Science,

International Islamic University Malaysia,

Jalan Sultan Ahmad Shah,

25200 Kuantan, Pahang.

Email: chenurulainicheamri@iium.edu.my least 3000 species in some 250 genera with centre of distributions in Indo-Malaysia, Africa (including Madagascar), northern South America, Central America and Mexico; with thirty-five genera being native or naturalized in Peninsular Malaysia. ${ }^{4}$ Mc Dade et al. divided Acanthaceae into four families; Acanthoideae, Andrographideae, Nelsonioideae and Thunbergioideae. ${ }^{5}$ One of the major characteristics in Acanthaceae is the presence of cystoliths that are visible with magnifying lens as rod-shaped especially in the epidermis surfaces of the leaves, except in subfamilies Nelsonioideae and Thunbergiodeae and in the tribe of Acantheae. ${ }^{6}$ The presence of a unique fruit type with seed bornes on retinacula also recognised as one of the main characteristics that can be used for classification in Acanthaceae.

Acanthus and Andrographis are classified under subfamily Acanthoideae while Andrographis belongs to subfamily Andrographideae. ${ }^{5}$ Burkill reported that 103 species from West Tropical Africa are known as 'useful plant' even though Acanthaceae is not listed for economic purposes. ${ }^{7}$ Wiart identify Acanthus as an ornamental plant and traditionally used for medical treatment. ${ }^{8}$ In Malaysia the seed of $A$. ebracteatus is used to expel intestinal worms, while the roots is used to treats shingles. The roots of $A$. ilicifolius is also useful for the treatment of cancer, relieving cough and asthma. The usefulness of Andrographis paniculata leaves as medicinal herbs especially to threats of infectious diseases. ${ }^{9}$ Solomon et al. described Asystasia gangetica subsp. micrantha as one of the herbs that is used in folk medicine for managing hypoglycemia associated with diabetes. ${ }^{10}$ 
Currently, herbal medicine is gaining acceptance as an alternative medicine and therefore, more herbal drugs are available in the market in various forms such as pills or drinks. ${ }^{11}$ Due to high demand from the herbal industries, the price for the raw materials also increased. Therefore, it is very important to identify plants accurately before pharmacognosists can proceed to get new chemical substances from these plants. According to Cutler et al., the proper authentication for drug materials is essential for standards of safety and quality that have to be maintained. For herbal remedies used as folk medicines, especially from tropical parts of the world, are mostly fragmentary in nature. ${ }^{12}$ Therefore, the anatomical methods of identification is needed to identification of such fragments. ${ }^{12}$ Besides, the study of plant anatomy is also very important in the identification of species especially in the absence of floral and fruiting materials. ${ }^{11}$ The complete anatomical description of the plant organs may very useful in order to identify cells and tissue fragments for the confirmation of species in herbal products. ${ }^{11}$ In the past taxonomist had difficulties in identifying and classifying species in Acanthaceae due to morphological similarities with other species in the same genus. Therefore, the purpose of this study is to evaluate the taxonomic significance of the anatomy of the leaf in selected species of Acanthaceae, in order to provide useful additional data for identification and classification species in Acanthaceae.

\section{MATERIALS AND METHODS}

This study was conducted on three taxa of Acanthaceae (Acanthus ebracteatus, Andrographis paniculata, Chroesthes longifolia). Fresh leave samples were collected from several forest reserves and mangrove areas in peninsular Malaysia such as in Larut Matang, Perak and Mersing, Johor. Voucher specimens of fresh leave samples were deposited at Universiti Kebangsaan Malaysia Herbarium (UKMB). Fresh leave samples were fixed in 3:1 AA Solutions (70\% Alcohol: 30\% Acetic Acid). Part of petioles, midribs, leaf lamina and marginal were sectioned in a range of thickness $(15-40 \mu \mathrm{m})$ using a sliding microtomes and stained using Safranin and Alcian blue. Slides were mounted in Euparal after dehydration. Anatomical images were captured using a video (3CCD) camera attached to a Leitz Diaplan microscope using Cell^ $B$ software. Suitable modifications in term of fixation and embedding followed the method by Johansen and Sass. ${ }^{13,14}$

\section{RESULTS AND DISCUSSION}

Findings in this study have shown some commons and variations of leaf anatomical characteristics that can be used in identification and classification in Acanthaceae. Three common characters have been identified in all taxa studied which is the presence of collenchyma layers in petiole and midrib (Fig. $1 \mathrm{~A} \& \mathrm{~B}$ ), the presence of mucilaginous idioblast cells (Fig. $1 C \& D$ ) and also the presence of trichomes either in petiole, midrib or lamina (Fig.
1 E \& F). O'Neill state that the thickness of collenchyma cells allow the stems to be strong and also to protect it from the wind. ${ }^{15}$ Therefore, the presence of collenchyma cells in petiole and midrib in all taxa studied is useful especially in identification of Acanthaceae family. Trichomes were observed in all taxa studied. During the revision of Deppa (tribe Hamelieae) by Lorence and Dwyer, they stated that the type, size and distribution of trichomes as important characters in identification of plant species. ${ }^{16}$ Majority of peltate trichomes were found in all taxa studied.

Results of this study also have shown the variation in leaf anatomical characteristics that can be used in differentiation of taxa in Acanthacaeae. These characters are as follows; 1) petiole and midrib outlines, 3) type of vascular bundles in petiole and midrib, 4) presence of cystolith cells 5) presence of hypodermal layers (Table 1). Petiole outline were described based on adaxial and abaxial outlines whilst the type of vascular bundle arrangements were described based on peripheral, medullary and extra vascular bundles. According to Noraini et al., petiole outline can be used for identification of some species in genus Coelostegia (Bombacaceae). ${ }^{17}$ Nurul-Aini et al. also reported the significance of petiole outlines in classification species of genus Microcos in Tiliaceae. ${ }^{18}$ Three type of petiole outlines were observed in all taxa studied. Type 1 (adaxial convex with earlobe-like structures on the left and right petiole, abaxial $\mathrm{U}$-shaped with diverge wall slightly outwards) can be found in $A$. ebracteatus (Fig. 2A).

While Type 2 (adaxial with $1 / 2$ inverse rectangular and concave base with diverge wall, and also have wing-like structures on the left and right petiole, abaxial $1 / 2$ square with concave base and tapered wall) only recorded in $A$. paniculata (Fig. 2C). Type 3 (adaxial convex with earlobe-like structures on the left and right petiole, abaxial U-shaped with diverge wall outwards) present in C. longifolia (Fig. $2 \mathrm{E})$. Nurul-Aini ${ }^{19}$ described the significanceof midrib outlines especially in assist in the identification of species in Microcos (Tiliaceae). Three type of midrib outlines were described in all taxa studied. Type 1 (adaxial tuberous, abaxial UV shaped) present in $A$. ebracteatus (Fig. 3A). Type 2 (adaxial $1 / 2$ inverse rectangular with wing-like structures on the left and right midribs) can be found in A. paniculata (Fig. 3C). While type 3 (adaxial tuberous, abaxial Ushaped) observed in C. longifolia (Fig. 3E). Therefore, the variation in petiole and midrib outlines can be useful as additional data in identification some taxa in Acanthaceae.

Early research by Candolle in his first comprehensive study of petiole anatomy explained the several fundamental concepts of vascular bundles. ${ }^{20} \mathrm{He}$ described two types of vascular systems between 'opened system' and 'closed system'. Ruzi et al. ${ }^{21}$ stated that the genus Dipterocarpus (Dipterocarpaceae) can be divided into five groups based on the vascular bundles 
arrangement in the petioles. He also reported that the characteristics of vascular bundle patterns in the petiole have significance especially in species authentication in Dipterocarpus. Three type of vascular bundles arrangement were found in petioles of all taxa studied. In Type 1, there are two main vascular bundles which is peripheral and extra vascular bundles. Peripheral vascular bundle has closed system with continuous ring of vascular bundle while extra vascular bundles has closed system with four continuous ring of vascular bundles in both right and left at the adaxial surfaces, and the size of vascular bundles are getting smaller towards the petiole lobes (Fig. 2 B).
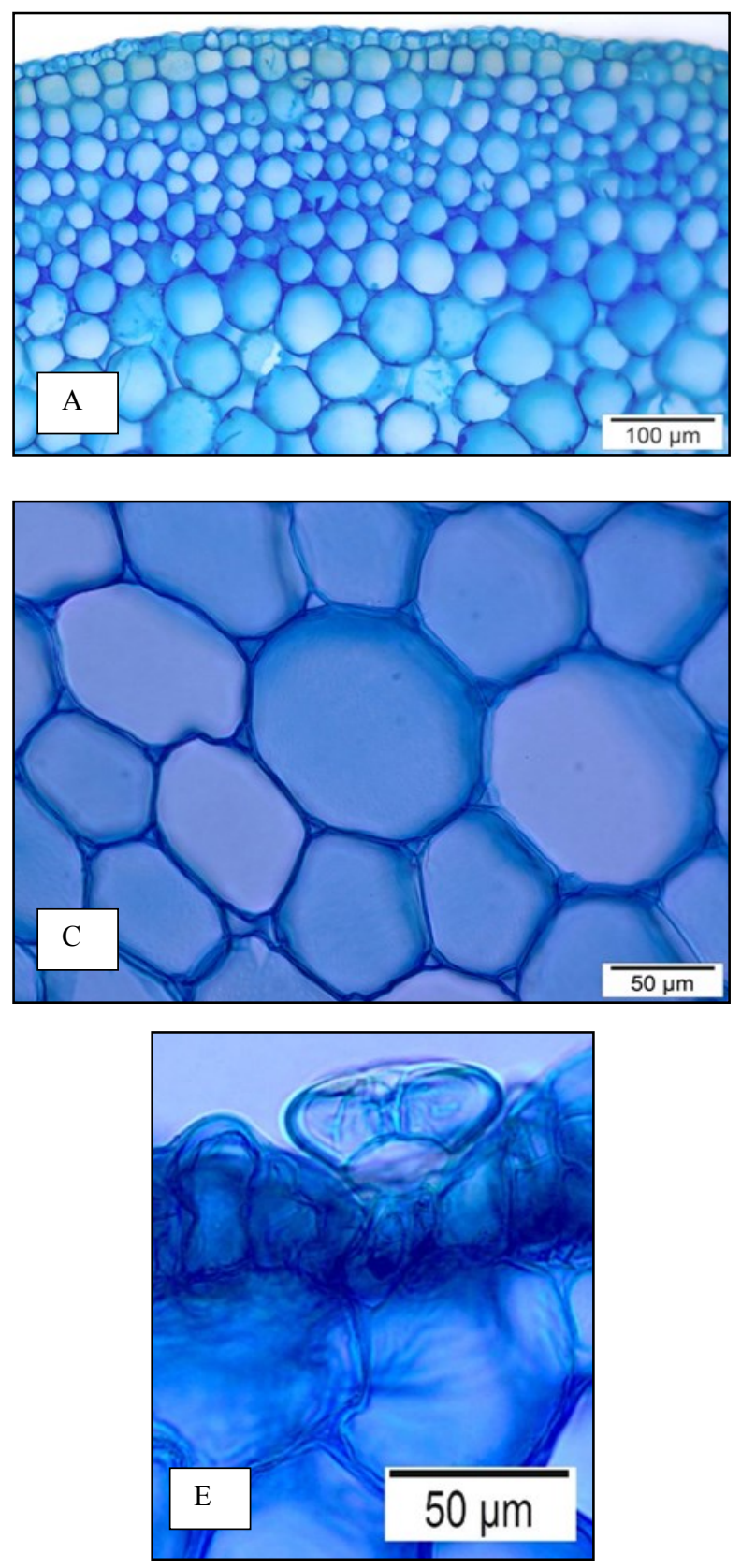

Type 1 presents in A. ebracteatus only. In Type 2, there are also two main vascular bundles were described which is peripheral and extra vascular bundles. Peripheral vascular bundles has opened system with U-shaped interrupted ring while extra vascular bundles has opened system with four simple vascular bundles in both right and left at the adaxial surfaces (Fig. 2 D). This type presents in $A$. paniculata. Type 3 , on the other hand also has two main vascular bundles which are peripheral vascular bundles and extra vascular bundles. Peripheral vascular bundles has opened system with U-shaped continuous ring while extra vascular bundles has opened system with two simple vascular bundles in both right and left at the adaxial surfaces (Fig. 2 F). Type 3 were observed in C. longifolia.
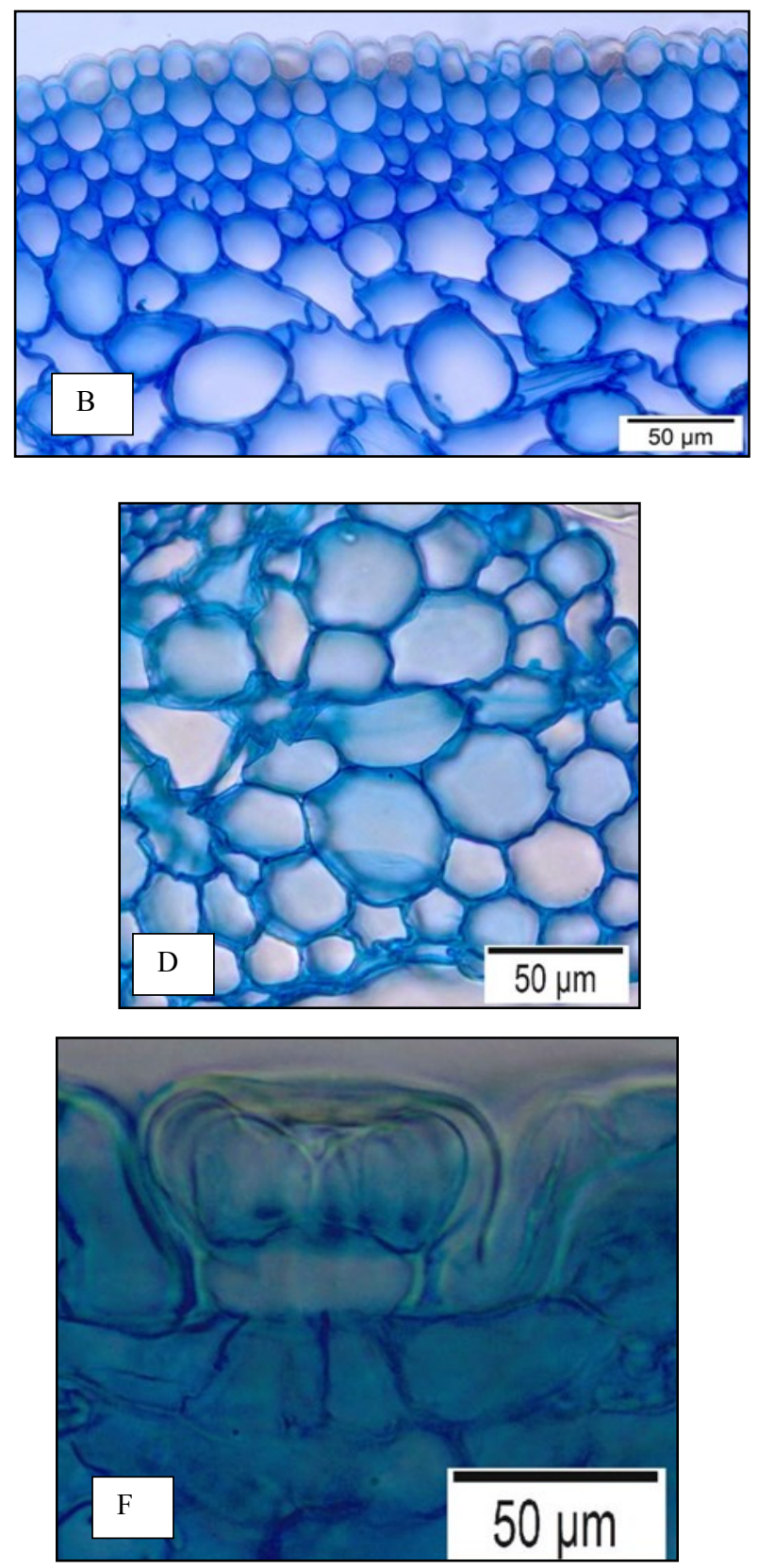

Figure 1. The common anatomical characteristics in all taxa studied: A) Collenchyma layers in petioles of $A$. ebracteatus, B) Collenchyma layers in midribs of $A$. ebracteatus, C) The presence of mucilaginous idioblast cells in petiole of $C$. longifolia, D) The presence of mucilaginous idioblast cells in midrib of $A$. paniculata E) The presence of peltate trichomes in petiole of $C$. longifolia, F) The presence of peltate trichomes in lamina of $A$. ebracteatus. 

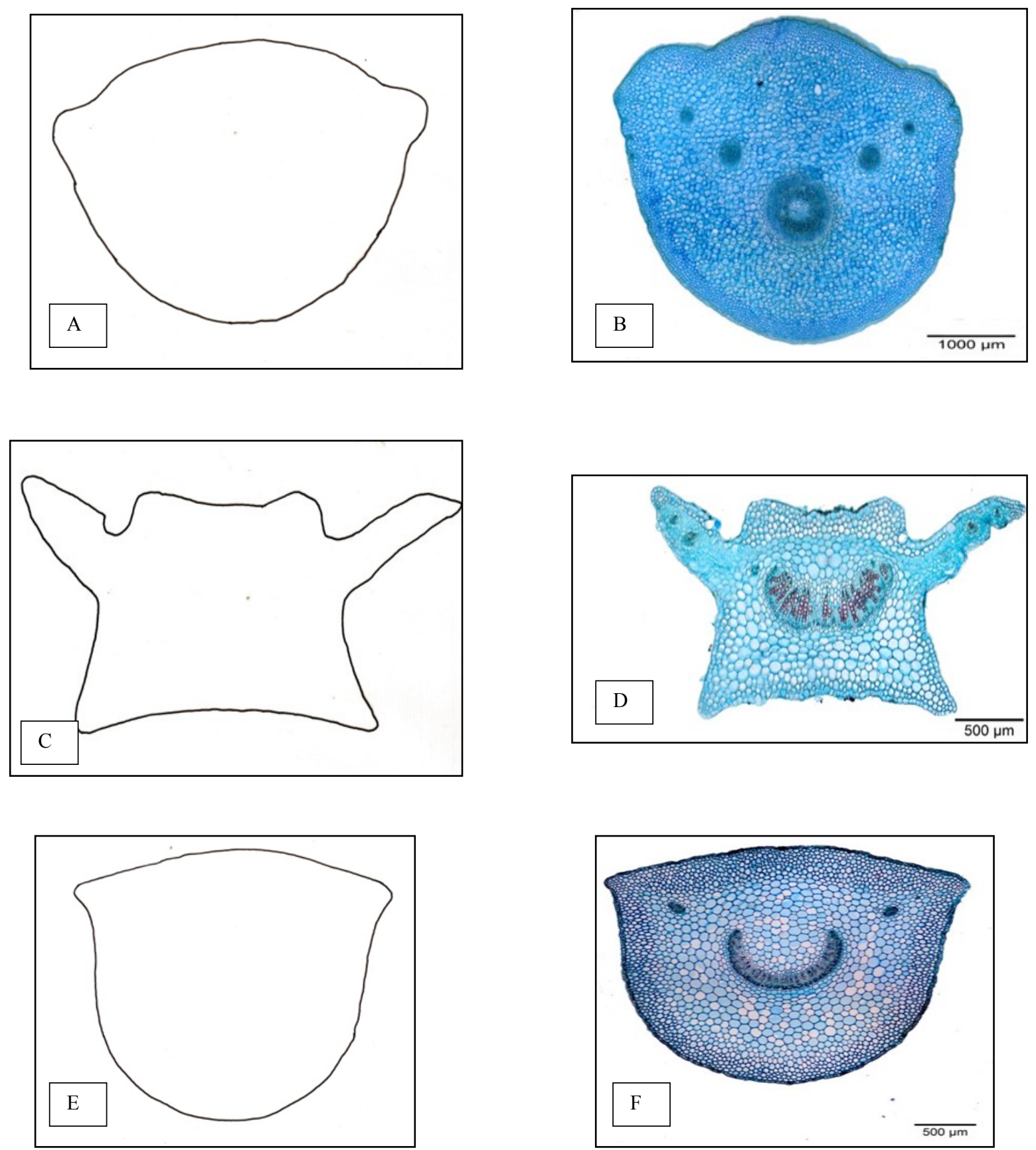

Figure 2. Cross section of petiole: A) The petiole outline of A. ebracteatus, B) The vascular bundles arrangement in petiole of A. ebracteatus, C) The petiole outline of A. paniculata, D) The vascular bundles arrangement in petiole of $A$. paniculata, E) The petiole outline of $C$. longifolia, F) The vascular bundles arrangement in petiole of $C$. longifolia

Previous study by Nurul-Aini identified the vascular bundles arrangement in midrib can be used to differentiate between two species in genus Grewia which is $G$. laevigata and $G$. polygama. ${ }^{19}$ Results show that presence of three type of vascular bundles arrangement in midribs of all taxa studied. In Type 1 , there are two main vascular bundle arrangements described as peripheral vascular bundles and extra vascular bundles. Peripheral vascular bundles has closed system with $\mathrm{O}$-shaped continuous ring while extra vascular bundles has opened system with two vascular bundle $\mathrm{U}$-shaped continuous rings (Fig. $3 \mathrm{~B}$ ).
Type 1 presents in A. ebracteatus. Compared with Type 2, there are only one vascular bundle were described which only have one opened system with $U$ shaped interrupted ring .(Fig. $3 \mathrm{D}$ ). This type of vascular bundles can be found in $A$. paniculata. Whilst Type 3 also have one simple vascular bundle which is opened system with $\mathrm{U}$-shaped continuous ring and present in $C$. longifolia (Fig. $3 \mathrm{~F}$ ). Findings in this study has shown the variations in vascular bundles arrangement in petiole and midrib is highly taxonomic significance and can be used to distinguish taxa in Acanthaceae. 

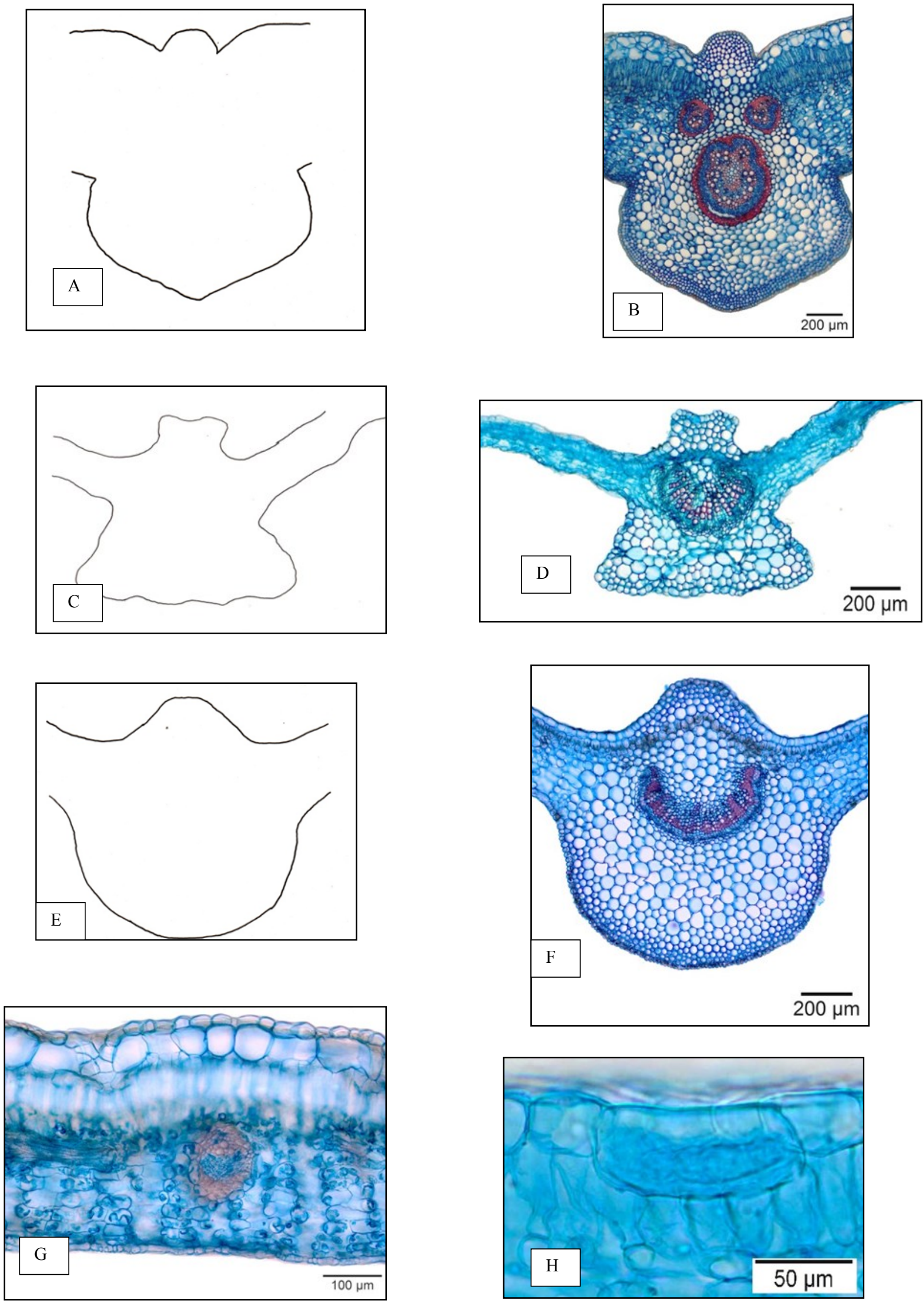

Figure 3. Cross section of midrib and lamina: A) The midrib outline of A. ebracteatus, B) The vascular bundles arrangement in midrib of $A$. ebracteatus, C) The midrib outline of $A$. paniculata, D) The vascular bundles arrangement in midrib of $A$. paniculata, E) The midrib outline of $C$. longifolia, F) The vascular bundles arrangement in midrib of of $C$. longifolia, $\mathrm{G}$ ) The presence of hypodermal layers in lamina of $A$. ebracteatus, $\mathrm{H}$ ) The presence of cystolith cells in $A$. paniculata. 
Table 1 Summary of leaf anatomical characteristics in all taxa studied

\begin{tabular}{|c|c|c|c|c|c|}
\hline $\begin{array}{c}\text { Taxon } \\
\text { /characters }\end{array}$ & $\begin{array}{l}\text { Petiole and midrib } \\
\text { outlines }\end{array}$ & $\begin{array}{l}\text { Vascular bundles in } \\
\text { petiole }\end{array}$ & $\begin{array}{l}\text { Vascular bundles in } \\
\text { midrib }\end{array}$ & $\begin{array}{l}\text { Presence of } \\
\text { systolith } \\
\text { cells }\end{array}$ & $\begin{array}{c}\text { Presence of } \\
\text { hypodermal } \\
\text { layers }\end{array}$ \\
\hline $\begin{array}{l}\text { Acanthus } \\
\text { ebracteatus }\end{array}$ & $\begin{array}{l}\text { Petiole - Type } 1 \\
\text { (adaxial convex with } \\
\text { earlobe-like } \\
\text { structures on the } \\
\text { left and right } \\
\text { petiole, abaxial U- } \\
\text { shaped with diverge } \\
\text { wall slightly } \\
\text { outwards) Midrib - } \\
\text { Type } 1 \\
\text { (adaxial tuberous, } \\
\text { abaxial UV shaped) }\end{array}$ & $\begin{array}{l}\text { Type } 1 \\
\text {-Peripheral vascular } \\
\text { bundle has closed } \\
\text { system with } \\
\text { continuous ring of } \\
\text { vascular bundle } \\
\text {-Extra vascular } \\
\text { bundles has closed } \\
\text { system with four } \\
\text { continuous ring of } \\
\text { vascular bundles in } \\
\text { both right and left } \\
\text { at the adaxial } \\
\text { surfaces }\end{array}$ & $\begin{array}{l}\text { Type } 1 \\
\text {-Peripheral vascular } \\
\text { bundles has closed } \\
\text { system with O-shaped } \\
\text { continuous ring } \\
\text {-Extra vascular } \\
\text { bundles has opened } \\
\text { system with two } \\
\text { vascular bundle U- } \\
\text { shaped continuous } \\
\text { rings }\end{array}$ & - & Present \\
\hline $\begin{array}{l}\text { Andrographis } \\
\text { paniculata }\end{array}$ & $\begin{array}{l}\text { Petiole - Type } 2 \\
\text { (adaxial with } 1 / 2 \\
\text { inverse rectangular } \\
\text { and concave base } \\
\text { with diverge wall, } \\
\text { and also have wing- } \\
\text { like structures on } \\
\text { the left and right } \\
\text { petiole, abaxial } 1 / 2 \\
\text { square with concave } \\
\text { base and tapered } \\
\text { wall) } \\
\text { Midrib - Type } 2 \\
\text { (adaxial } 1 / 2 \text { inverse } \\
\text { rectangular with } \\
\text { wing-like structures } \\
\text { on the left and right } \\
\text { midribs) }\end{array}$ & $\begin{array}{l}\text { Type } 2 \\
\text {-Peripheral vascular } \\
\text { bundles has opened } \\
\text { system with U- } \\
\text { shaped interrupted } \\
\text { ring } \\
\text {-Extra vascular } \\
\text { bundles has opened } \\
\text { system with four } \\
\text { simple vascular } \\
\text { bundles in both } \\
\text { right and left at the } \\
\text { adaxial surfaces }\end{array}$ & $\begin{array}{l}\text { Type } 2 \\
\text {-One vascular bundle } \\
\text { with one opened } \\
\text { system with U- shaped } \\
\text { interrupted ring }\end{array}$ & Present & \\
\hline $\begin{array}{l}\text { Chroesthes } \\
\text { longifolia }\end{array}$ & $\begin{array}{l}\text { Petioe Type } 3 \\
\text { (adaxial convex with } \\
\text { earlobe-like } \\
\text { structures on the } \\
\text { left and right } \\
\text { petiole, abaxial U- } \\
\text { shaped with diverge } \\
\text { wall outwards) } \\
\text { Midrib - Type } 3 \\
\text { (adaxial tuberous, } \\
\text { abaxial U-shaped) }\end{array}$ & $\begin{array}{l}\text { Type } 3 \\
\text {-Peripheral vascular } \\
\text { bundles has opened } \\
\text { system with U- } \\
\text { shaped continuous } \\
\text { ring } \\
\text {-Extra vascular } \\
\text { bundles has opened } \\
\text { system with two } \\
\text { simple vascular } \\
\text { bundles in both } \\
\text { right and left at the } \\
\text { adaxial surfaces. }\end{array}$ & $\begin{array}{l}\text { Type } 3 \\
\text {-One vascular bundle } \\
\text { with one opened } \\
\text { system with U-shaped } \\
\text { continuous ring }\end{array}$ & Present & \\
\hline
\end{tabular}

The presence of hypodermal layers are different for each species which is the layers can be observe either underneath adaxial or abaxial epidermis or both underneath adaxial and abaxial epidermis in the leaf lamina, petiole, midrib and margin. ${ }^{22}$ An earlier study conducted by Metcalfe and Chalk recorded the presence of hypodermal layers of some species in family Acanthaceae. ${ }^{23}$ Results of this study show the presence of hypodermal layers in Acanthus only (Fig. $3 \mathrm{G}$ ). Cutler et al. argues that the presence and thickness of the layer of hypodermic affected by habitat and environment as well as the intensity of the light. ${ }^{12}$ This study may also explain that the presence of hypodermal layers in Acanthus are related with the habitat environment which is the habitat for the Acanthus is mangrove forests.

Eventhough the presence of cystolith cells have significantly lower values for plant taxonomy and is rarely used in the classification of the species or genus, but this characteristics of cystolith cells is very useful in some families like Moraceae, Acanthaceae,Urticaceae and Boraginaceae. Metcalfe and Chalk also recorded the presence of cystolith cells especially in leaf anatomy that have taxonomic 
significance in Acanthaceae especially in identification and classification of genus and species. ${ }^{23}$ The results of this study showed the presence of cystolith cells in A. paniculata and $C$. longifolia except in $A$. ebracteatus (Fig. $3 \mathrm{H}$ ).

\section{CONCLUSIONS}

Leaf anatomical characteristics have significance data especially for identification and classifications of Acanthaceae. Findings in this study indicate some variations in anatomical characters that has systematic significances especially in identification species and genus in Acanthaceae which is 1) Type of petiole and midrib outlines, 2) Type of vascular bundles in petiole and midrib, 4) presence of cystolith cells and 5) presence of hypodermal layers.

\section{ACKNOWLEDGEMENTS}

We wish to thank the International Islamic University Malaysia, Universiti Kebangsaan Malaysia and RIGS 16-095-0259 Research Grants which sponsored this research.

\section{REFERENCES}

1. Ahmed AT, Mohammed FS, Wael FB, Leon B Exploration of Islamic medicine plant extracts as powerful antifungals for the prevention of mycotoxigenic Aspergilli growth in organic silage J Sci Food Agric. 2011; 2160-2165.

2. Saad B Greco-Arab and Islamic Herbal Medicine: A review. European Journal of Medicinal Plants 2014; 4(3): 249-258.

3. Scotland RW, Sweere JA, Reeve PA, Olmstead RG. Higher level systematics of Acanthaceae determined by chloroplast DNA sequences. American Journal of Botany 1995; 82: 266-275.

4. Keng H Orders and Families of Malayan Seed Plants Singapore: Singapore University Press, 2003.

5. MCDade LA, Daniel TF, Kiel CA Toward a comprehensive understanding of phylogenetic relationships among lineages of Acanthaceae S.L. (Lamiales). American Journal of Botany 2008; 95(9): 1136-1152.

6. Heywood VH, Brummitt RK, Culham A, Seberg 0 Flowering Plants Families of The World, Canada: Firefly Books, 2007.

7. Burkill HM The useful plants of West Tropical Africa. Vol. 1. Families A-D. Kew: Royal Botanic Garden, 1985.

8. Wiart C Medicinal Plants of Southeast Asia. Kuala Lumpur: Pearson Malaysia Sdn. Bhd, 2002.

9. Coon JT, Ernst E Andrographis paniculata in the treatment of upper respiratory tract infections: a systematic review of safety and efficacy. Planta Med 2004; 70: 293-298.

10. Solomon OR, Omolola EO, Oluwakemi AR. Persistence of acidosis in alloxan-induced diabetic rats treated with the juice of Asystasia gangetica leaves. Pharmacogn Mag 2011; 7 (25):25-30.

11. Khatijah $\mathrm{H}$, Ruzi MAR Anatomical Atlas of
Malaysian Medicinal Plants. Vol. 2. Bangi:UKM Press, 2006.

12. Cutler DF, Botha CEJ, Stevenson DW Plant Anatomy: An Applied Approach. New York: Blackwell Publishing, 2008.

13. Johansen DA Plant Microtechnique. New York: McGraw Hill Publication, 1940.

14. Saas JE Botanical Microtechnique. 3rd Edition. Ames: lowa State University, 1958.

15. O'Neill CS. Anatomy of the shrimp plant, Justicia brandegeana (Acanthaceae). Studies by Undergraduate Researchers at Guelph 2010; 3 (2): 41-47.

16. Lorence DH, Dwyer JD A revision on Deppea (Rubiaceae). Allertonia 1988; 7(4): 389 - 436.

17. Noraini T, Solihani NS, Khatijah H, Chung RCK. Comparative petiole and midrib anatomical characters in selected species of Coelostegia (Bombacaceae) in Malaysia. $3^{\text {rd }}$ regional Symposium on Environment and Natural Resources, 5-6 August 2008. Prince Hotel and Residence, Kuala Lumpur, pg. 712-716, 2008.

18. Nurul-Aini CAC, Noraini T, Latiff A, Chung RCK, Nurhanim MN, Ruzi M. Systematic Significance of Petiole Anatomical Characteristics in Microcos L. (Malvaceae: Grewioideae). Malayan Nature Journal 65 2013; (2\&3): 145-170.

19. Nurul-Aini CAC Kajian anatomi dan mikromorfologi daun ke atas genus Grewia $\mathrm{L}$ dan Microcos L (Malvaceae subfamili Grewioideae), Thesis Master of Science, Faculty of Science and Technology, Universiti Kebangsaan Malaysia, 2011.

20. Candolle CDE Anatomie compare des feulles chez quelques familles de Dicotyledones. Mémoires de la Société de Physique et d'Histoire Naturelle de Genève 1879; 26: 427480.

21. Ruzi AR, Hussin K, Noraini T Systematic significance of the petiole vascular bundles types in Dipterocarpus Gaertn. $f$. (Dipterocarpaceae). Malaysian Applied Biology 2009; 38(2): 11-16.

22. Metcalfe CR, Chalk L. Anatomy of the Dicotyledons. No 1. Oxford: The Clarendon Press, 1979.

23. Metcalfe CR, Chalk L Anatomy of the Dicotyledons. No 1. Oxford: The Clarendon Press, 1965. 
